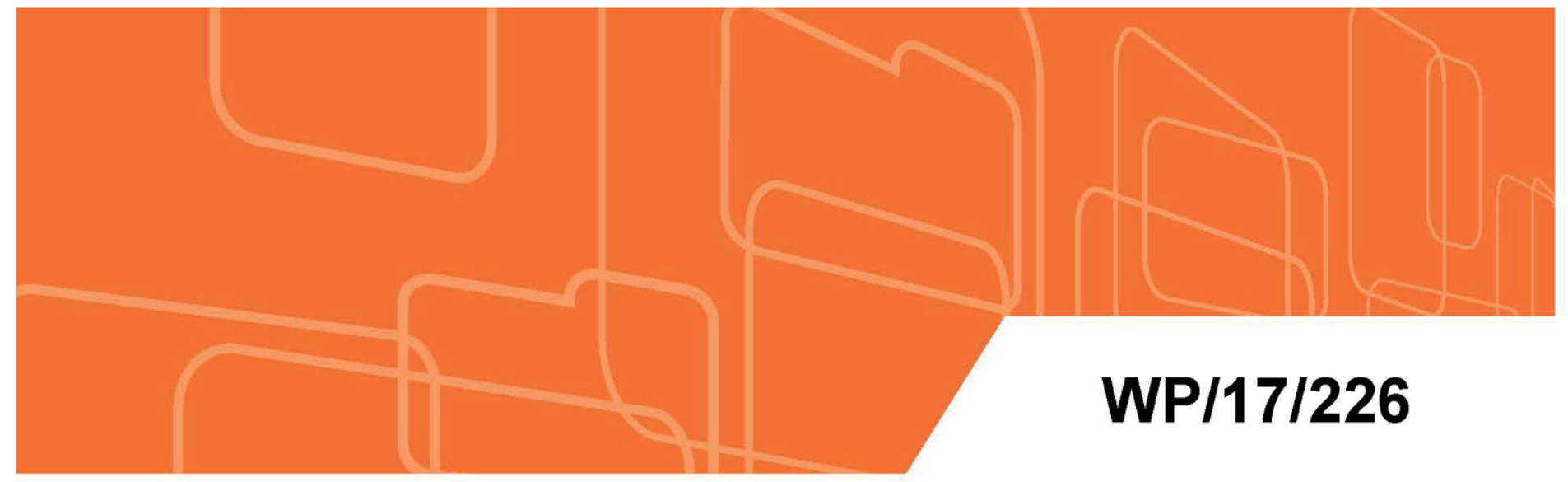

IMF Working Paper

\title{
Liquidity Stress Tests for Investment Funds: A Practical Guide
}

by Antoine Bouveret

IMF Working Papers describe research in progress by the author(s) and are published to elicit comments and to encourage debate. The views expressed in IMF Working Papers are those of the author(s) and do not necessarily represent the views of the IMF, its Executive Board, or IMF management. 


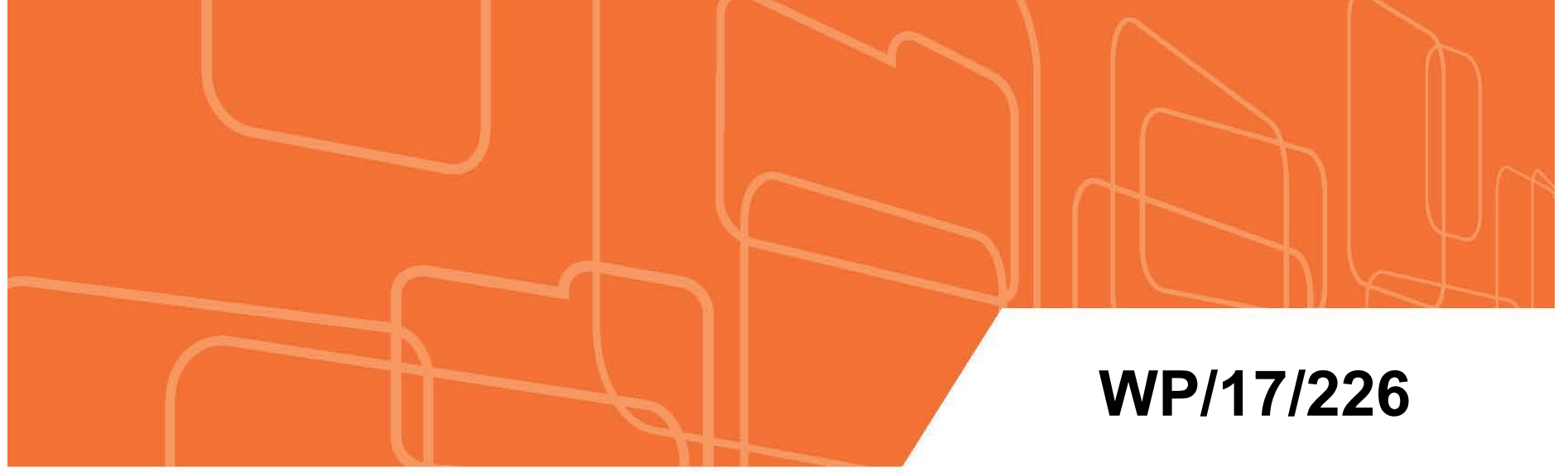

\section{IMF Working Paper}

\section{Liquidity Stress Tests for Investment Funds: A Practical Guide}

by Antoine Bouveret

IMF Working Papers describe research in progress by the author(s) and are published to elicit comments and to encourage debate. The views expressed in IMF Working Papers are those of the author(s) and do not necessarily represent the views of the IMF, its Executive Board, or IMF management. 


\title{
IMF Working Paper
}

Monetary and Capital Markets Department

\section{Liquidity Stress Tests for Investment Funds: A Practical Guide \\ Prepared by Antoine Bouveret* \\ Authorized for distribution by Daniel Hardy}

October 2017

\section{This Working Paper should not be reported as representing the views of the IMF.} The views expressed in this Working Paper are those of the author(s) and do not necessarily represent those of the IMF or IMF policy. Working Papers describe research in progress by the author(s) and are published to elicit comments and to further debate.

\begin{abstract}
This paper outlines a framework to perform liquidity stress tests for investment funds. Practical aspects related to the calibration of the redemption shock, the measurement of liquidity buffers and the assessment of the resilience of investment funds are discussed. The integration of liquidity stress tests with banking sector stress tests and possible bank-fund interlinkages are also covered.
\end{abstract}

JEL Classification Numbers: E44, G12, G23

Keywords: stress test, liquidity, investment funds, redemption

Author's E-Mail Address: abouveret@imf.org.

\footnotetext{
* The author would like to thank Peter Breuer, Cristina Cuervo, Daniel Hardy, Bradley Jones, Ivo Krznar, Sheheryar Malik, Rebecca McCaughrin, and Steven Phillips for their comments on a previous version of this paper.
} 
Abstract

I. Introduction $\underline{4}$

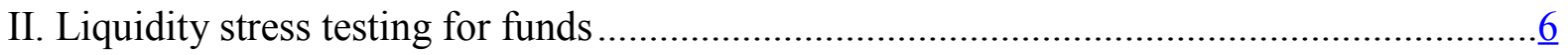

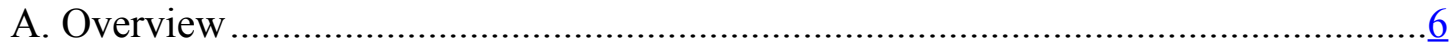

B. Calibration of the redemption shock ...........................................................

C. Measurement of Liquidity Buffers …........................................................ 12

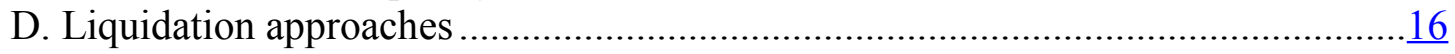

E. How to Measure the Resilience of Investment Funds ......................................17

III. Bank-fund interlinkages................................................................................. 22

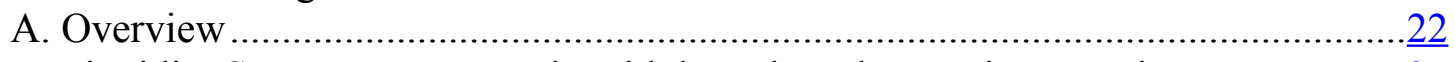

B. Liquidity Stress Tests, Deposit Withdrawals and Depositary Banks ......................

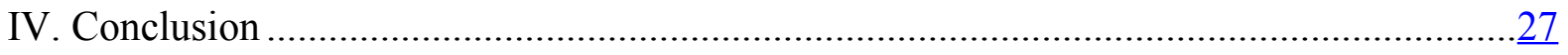

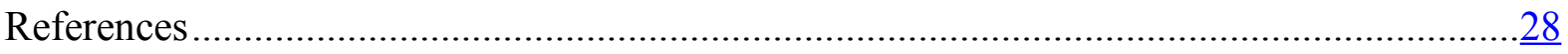

Figures

Figure 1. Growth of the Asset Management Industry .................................................. 4

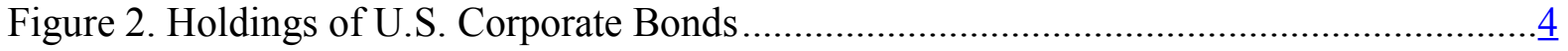

Figure 3. Growth of EM Bond Funds .................................................................... 4

Figure 4. Growth of HY Bond Funds ............................................................................. 4

Figure 5. Representation of the liquidity stress test .......................................................

Figure 6. Observed and Estimated Net Flows by Fund Strategy .....................................12

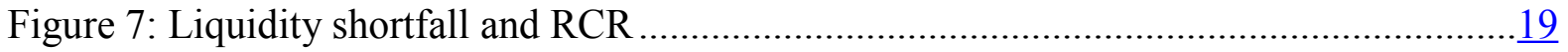

Figure 8. Liquidity Shortfall for Selected Funds ...........................................................19

Figure 9. Liquidity stress test results for Irish EM and HY funds ...................................

Figure 10. Liquidity Stress Tests Results for the U.S.....................................................21

Figure 11. Liquidity Stress Test Results for Sweden.....................................................22

Figure 12. Bank Liabilities Accounted for by investment funds and MMFs in Luxembourg. 24

Tables

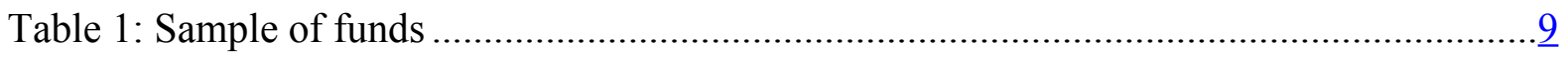

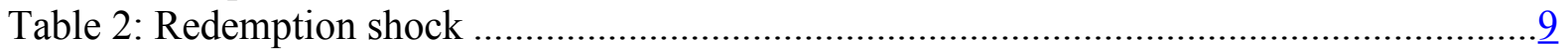

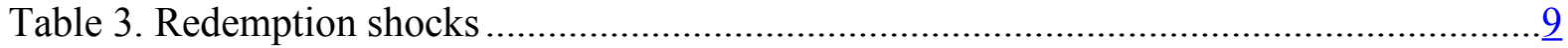

Table 4. Macrofinancial variables in the adverse scenario ...............................................11

Table 5. Projected net outflows in the adverse scenario .................................................. 11

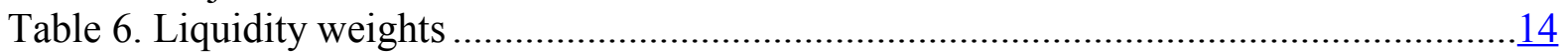

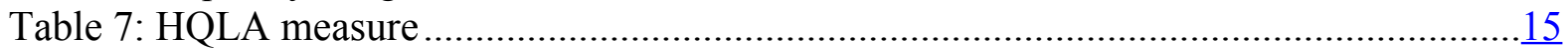

Table 8. Liquidity buffers (percent of total net assets) ..................................................16

Table 9. Methods used for liquidity stress tests for funds in recent FSAPs ........................17

Table 10: Stress test results ...................................................................................... 18

Table 11. Stress test results for the historical approach ............................................. 20

Table 12. Stress test results for the macroeconomic approach ..........................................

Table 13. Euro Area Investment Funds Exposures to Euro Area Banks ...............................23 
Table 14. Luxembourg Investment Funds Exposures to Banks .$\underline{24}$

Table 15. Deposit Outflows Under the Forward-Looking Approach .....................................

Appendix

I. Estimating HQLA Measures Using Aggregated Data................................................ 30 


\section{INTRODUCTION}

The asset management industry has experienced spectacular growth over the last decade (Figure 1). With a significant market footprint in some asset classes such as U.S. corporate bonds (Figure 2), Emerging Market (EM) debt (Figure 3) and High Yield (HY) bonds (Figure 4), distress in the fund sector could amplify risks for issuers, investors, banks and finally financial stability. ${ }^{1}$ Therefore, there has been a growing interest in financial stability risks arising from the fund industry (OFR (2013), IMF (2014a)).

Figure 1. Growth of the Asset Management Industry

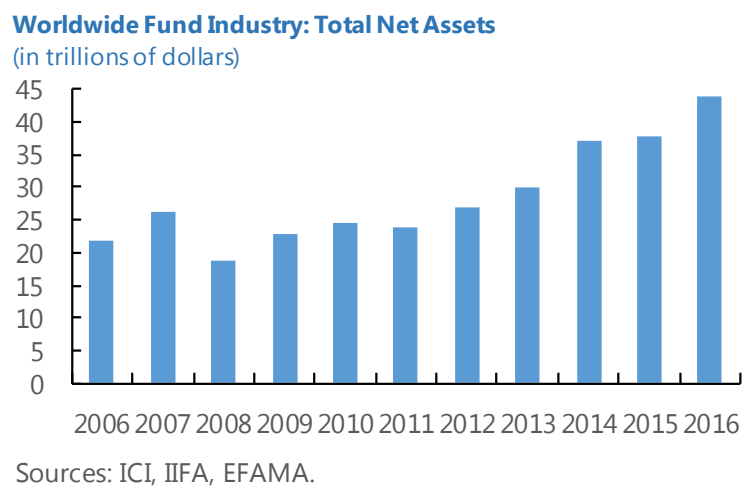

Figure 3. Growth of EM Bond Funds

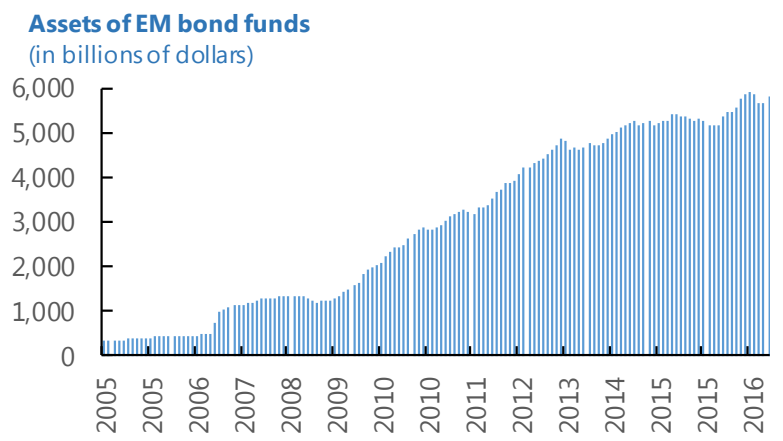

Source: EPFR.
Figure 2. Holdings of U.S. Corporate Bonds

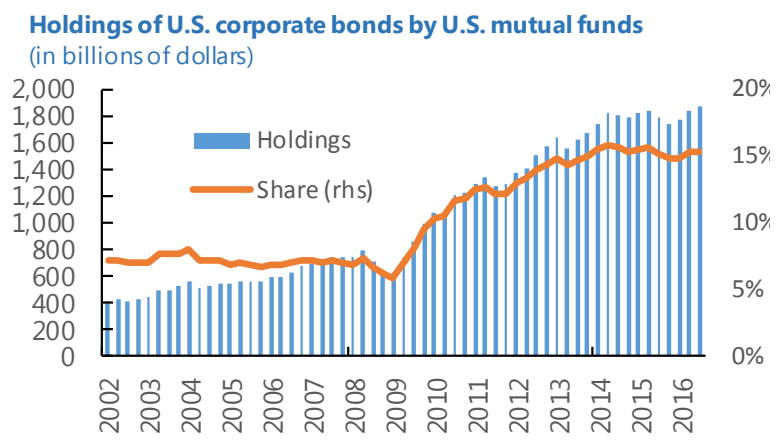

Sources: Flow of Funds, IMF staff.

\section{Figure 4. Growth of HY Bond Funds}

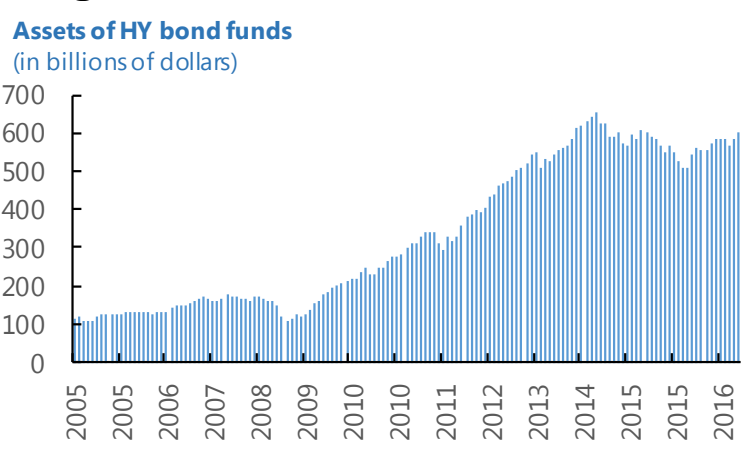

Source: EPFR.

A particular focus has been on liquidity mismatch, as most investment funds (UCITS in the EU, mutual funds in the U.S.) offer daily liquidity to investors, while they can invest in less liquid asset classes (HY or EM debt for example). If large redemptions would occur, funds might not be able to sell assets quickly enough, without experiencing large discounts on their sales and/or triggering price spirals (IMF (2015a), IMF (2015b)). Since investment funds are investment vehicles, risks are borne by investors not asset management companies, and are reflected in the floating net asset value of the fund. However, fire sales by funds could have

\footnotetext{
${ }^{1}$ In this paper, 'investment funds' refer to collective investment vehicles. Investment funds cover mainly collective investment vehicles regulated under the Investment Company Act of 1940 in the U.S. ("mutual funds') and under the Undertakings for the Collective Investments in Transferable Securities Directive ('UCITS Directive') in the European Union.
} 
an impact on other agents by triggering price spirals in the market the funds invest in. The fire sales could in turn impact investors holding those securities, leading to second-round effects. Events such as the collapse of the U.S. HY Third Avenue Credit Focused Fund in December 2015 or the massive suspensions of redemptions among U.K real estate funds following the Brexit referendum in June 2016 provide evidence of how those risks could materialize, although in those cases spillovers were contained.

Fund managers typically perform stress tests related to market and credit risk, in line with regulatory requirements. Liquidity stress tests are also used, although there is little regulatory guidance on how to perform and report them, resulting in a wide range of practices among asset managers.

Therefore, policymakers such as the Financial Stability Board (FSB) have urged fund managers and regulators to develop liquidity stress tests, and to provide guidance on liquidity risk monitoring and liquidity risk management for investment funds to mitigate the risk of liquidity mismatch (FSB (2016), FSB (2017)). The FSB recommendations include disclosure requirements towards regulators and the public as well as the requirement to perform liquidity stress test for funds exposed to liquidity mismatch. However, while in the banking sector solvency and liquidity stress tests have been performed for a long time, and regulators have provided the industry with guidance, in the fund industry there has been little guidance on how to perform liquidity stress tests. ${ }^{2}$

The aim of this paper is to fill this gap by providing a framework for liquidity stress testing for funds that could easily be used by regulators or market participants. Operational aspects such as the calibration of redemption shocks and the measure of liquidity buffers are discussed and different approaches are suggested. The paper draws largely on the experience of recent IMF Financial Sector Assessment Programs (FSAPs) for advanced economies such as the U.S., Ireland, Sweden and Luxembourg.

The approaches suggested in this paper are simple to use and their data requirements are relatively limited. More sophisticated methods, which could also be used in practice by fund managers, are also discussed, but they tend to require more granular data and the use of models to estimate the price impact of trades which are not always available.

The rest of the paper is structured as follows. Section 2 presents the method used to perform liquidity stress tests. Section 3 provides some outcome of the liquidity stress tests for a sample of bond funds. Section 4 discusses the policy implications and concludes.

\footnotetext{
${ }^{2}$ There are a few exceptions. The association of the Luxembourg fund industry published guidelines on liquidity risk management for UCITS in 2013 (ALFI (2013)) and in France, the securities market regulator, the Autorité des Marchés Financiers (AMF) published a consultation paper on the use of stress tests in August 2016 (AMF (2016)). In the U.S., under SEC rule 2a7, MMFs are required to perform periodic stress tests based upon specified hypothetical events such as increases in short-term interest rates, ratings downgrades, increase in spreads combined with investors redemptions etc.
} 


\section{LIQUIDITY STRESS TESTING FOR FUNDS}

\section{A. Overview}

The objective of the liquidity stress test is to assess the resilience of investment funds -- at the individual level or at the industry level -- to severe, but plausible, redemption shocks. From a financial stability perspective, the resilience of individual funds is not an issue per se.

Investment funds stress tests can be used for multiple purposes. From a microprudential perspective, supervisors and other stakeholders can use stress test results to assess the resilience of a particular fund confronted with a redemption shock. From a financial stability perspective, if individual funds are not resilient, then redemption shocks could lead to large selling pressure which might not be able to be absorbed smoothly by markets, resulting in fire sales and price spirals.

Figure 5 shows the different components of the liquidity stress test. First, a redemption shock has to be set; various methods are available. Then, the redemption shock is compared to liquidity buffers on the asset side of the fund, which could be based on different metrics. Finally, a liquidation method has to be chosen, to model how the fund manager will react to the redemption shock (i.e. by selling its most liquid assets first or by selling its whole portfolio proportionally). Usually most funds will need to sell assets in proportion of their weight in the fund portfolio in order to preserve the structure of their portfolio and ensure its consistency with their investment policy.

Figure 5. Representation of the liquidity stress test

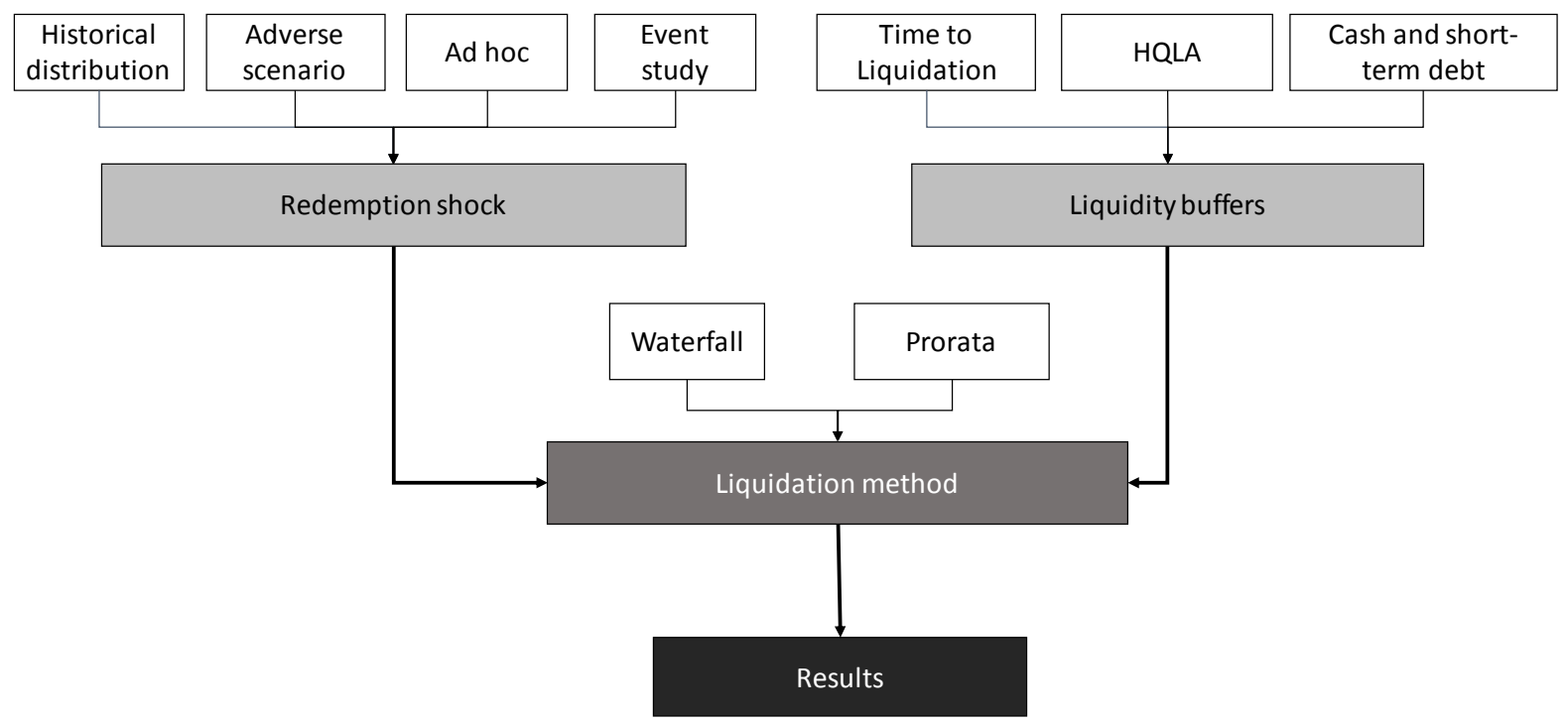

If liquidity buffers are not enough to cover the redemption shock, taking into account the liquidation method used by funds' managers, the fund does not 'pass' the stress test and the fund is more likely to trigger fire sales, especially if its portfolio is invested in less liquid securities, with limited depth. 
However, funds can use a range of tools to mitigate redemption risks such as: i) Liquidity Management Tools (LMTs), e.g. redemption fees, redemption gates, and/or ii) bank borrowing facilities available as temporary measures. Otherwise, a fund would need to suspend redemptions.

Note that the availability and effectiveness of LMTs are not covered in the liquidity stress test, as: i) there is uncertainty regarding their use and impact due to very limited empirical work on LMTs, and ii) the objective of stress tests is to assess the resilience of financial institutions without taking into account mitigating measures. ${ }^{3}$ The results of the liquidity stress tests should be seen in that context, remembering that the availability of LMTs at the fund level mitigates risks to some degree.

The next sections cover the calibration of the redemption shock, the measure of liquidity buffers, liquidation methods and finally, the assessment of the resilience of investment funds.

\section{B. Calibration of the redemption shock}

The redemption shock measures the net outflows the fund would be subject to in a severe, but plausible, scenario. The redemption shock is expressed as the net outflows in percentage of Total Net Assets (TNA) of a fund:

$$
\begin{aligned}
& \text { Flows }_{t}=\text { Inflows }_{t}-\text { Outflows }_{t} \\
& \text { flows }_{t}=\frac{\text { Flows }_{t}}{\text { TNA }_{t}}
\end{aligned}
$$

Ideally, flow data would need to be daily or weekly, but in most cases only monthly frequency is available. If flow data are not available, flows can be proxied using data on TNA and returns $R$, as it is common in the empirical literature on mutual funds (Coval and Stafford (2007)):

$$
\text { Flow }_{t}=T N A_{t}-T N A_{t-1} \times\left(1+R_{t}\right)
$$

Several methods could be used to calibrate the redemption shock: i) using event study based on specific historical events (e.g. the Lehman bankruptcy or the 2013 Taper Tantrum), ii) using an econometric model relating flows to macrofinancial variables (macroeconomic approach), iii) using ad hoc thresholds (5, 10 or 20 percent), or iv) using the historical distribution of net flows.

Two main methods will be discussed: the historical approach based on the distribution of net flows and the macroeconomic approach, since the two others (historical events and ad hoc)

\footnotetext{
${ }^{3}$ On the effectiveness of LMTs, an exception is Malik and Lindner (2017), which analyzes the effectiveness of swing pricing as a systemic risk mitigation technique.
} 
are straightforward to use. In both cases, a one-time shock is assumed, whereas stress test could also factor in consecutive shocks such as three consecutive months of outflows.

\section{Historical approach: worst 1 percent net flows}

For each fund in the sample, the distribution of net flows is computed, and the redemption shock is calibrated on the $1^{\text {st }}$ percentile of net flows in percent of TNA. ${ }^{4}$ The FSAPs for the U.S. (IMF (2015c), Sweden (IMF (2016b)) and Luxembourg (IMF (2017a), IMF (2017b)) used a similar threshold.

The net flows can be computed at the individual fund level or at an aggregate level (fund strategy or style): for the U.S. and Sweden, flows were computed at the fund style level, while for Luxembourg they were calculated at the individual fund level. The choice of aggregation has an impact on the interpretation of the results.

When redemption shocks are calibrated at the fund style level rather than individual fund level, the shocks will be typically lower since funds within the same category can observe inflows while others experience outflows.

In both cases, results would generally not be able to be aggregated beyond fund strategies, as it would assume that all funds are subject to the adverse shock at the same time, which might not be realistic. Indeed, net flows across funds pursuing different strategies can be negatively correlated: outflows from EM and HY funds can occur while Advanced Economies (AE) sovereign bond funds experience inflows due to flight to safety effects.

\section{A case study: top $50 \mathrm{HY}$ and EM bond funds in the U.S. and in Europe}

The analysis focuses on the largest HY and EM bond funds domiciled in the U.S. and in Europe (France, Germany, Ireland, Luxembourg and the U.K). The sample of 200 funds covers around $\$ 850$ billion in assets (Table 1) as of December 2016. Net flows are computed using data on TNA and returns over the period January 2006-December 2016. Due to data quality issues, absolute net flows above 50 percent of TNA are excluded. Redemption shocks are calibrated using each individual fund $1^{\text {st }}$ percentile of net flows (Table 2).

\footnotetext{
${ }^{4}$ In a few cases, the $1^{\text {st }}$ percentile of net flows might be positive, implying that the fund would face inflows under the historical approach.
} 
Table 1: Sample of funds

(Billions of dollars, unless specified)

\begin{tabular}{ccc}
\hline & $\begin{array}{c}\text { Number } \\
\text { of Funds }\end{array}$ & $\begin{array}{c}\text { Total Net } \\
\text { assets }\end{array}$ \\
\hline United States \\
EM & 50 & 193 \\
HY & 50 & 326 \\
Total U.S. & 100 & 519 \\
\hline \multicolumn{3}{c}{ Europe } \\
\hline HM & 50 & 118 \\
Total Europe & 50 & 208 \\
\hline Total & $\mathbf{2 0 0}$ & $\mathbf{8 4 5}$ \\
\hline
\end{tabular}

Sources: Bloomberg L.P., IMF Staff calculations
Table 2: Redemption shock

(in percent of TNA)

\begin{tabular}{cccrr}
\hline & Average & $\begin{array}{c}1 \text { st } \\
\text { Quartile }\end{array}$ & Median & $\begin{array}{c}\text { 3rd } \\
\text { Quartile }\end{array}$ \\
\hline \multicolumn{6}{c}{ United States } \\
\hline EM & $14 \%$ & $17 \%$ & $12 \%$ & $7 \%$ \\
HY & $9 \%$ & $11 \%$ & $7 \%$ & $6 \%$ \\
\hline \multicolumn{6}{c}{ Europe } \\
EM & $15 \%$ & $18 \%$ & $14 \%$ & $11 \%$ \\
HY & $13 \%$ & $17 \%$ & $13 \%$ & $10 \%$ \\
\hline
\end{tabular}

Sources: Bloomberg L.P., IMF Staff calculations

\section{A case study: Luxembourg}

In the Luxembourg FSAP, a sample of 191 funds, covering $€ 656$ billion in assets, was used. Fixed income funds were either EM, HY, mixed or other bond funds, while Money Market Funds (MMFs) were split among three groups: short-term Constant Net Asset Value (CNAV) MMFs, short-term Variable Net Asset Value (VNAV) MMFs and MMFs. Table 3 shows the calibration of redemption shocks for each type of fund based on individual monthly flows for 2007-2016. Overall, redemption shocks range between 15 and 20 percent of TNA, based on average on individual fund $1^{\text {st }}$ percentile of net flows over 2007-2016.

\section{Table 3. Redemption shocks}

\begin{tabular}{|c|c|c|c|c|}
\hline \multicolumn{5}{|c|}{ (percent of total net assets) } \\
\hline & \multicolumn{4}{|c|}{ Historical approach } \\
\hline & Average & $\begin{array}{c}\text { 1st } \\
\text { Quartile }\end{array}$ & Median & $\begin{array}{c}\text { 3rd } \\
\text { Quartile }\end{array}$ \\
\hline \multicolumn{5}{|c|}{ Bond funds } \\
\hline EM & $18 \%$ & $10 \%$ & $16 \%$ & $26 \%$ \\
\hline HY & $19 \%$ & $13 \%$ & $17 \%$ & $23 \%$ \\
\hline Mixed funds & $9 \%$ & $3 \%$ & $7 \%$ & $13 \%$ \\
\hline Other bond funds & $18 \%$ & $8 \%$ & $17 \%$ & $21 \%$ \\
\hline \multicolumn{5}{|c|}{ MMFs } \\
\hline Short Term CNAV & $19 \%$ & $15 \%$ & $17 \%$ & $23 \%$ \\
\hline Short Term VNAV & $23 \%$ & $19 \%$ & $23 \%$ & $27 \%$ \\
\hline Other MMFs & $18 \%$ & $13 \%$ & $15 \%$ & $22 \%$ \\
\hline
\end{tabular}




\section{Macroeconomic scenario}

A macroeconomic scenario can be used to calibrate the redemption shock. Banking sector solvency stress tests typically feature a baseline and an adverse scenario. This adverse scenario can then be used to calibrate the redemption shock for funds, provided that macrofinancial variables used in the adverse scenario have an impact on funds net flows.

Unlike the historical approach, the use of a macroeconomic scenario allows stress test results to be aggregated across funds, as all funds in the sample are subject to the same macrofinancial shocks at the same time. ${ }^{5}$

\section{A case study: Luxembourg}

For the Luxembourg FSAP, redemption shocks were also calibrated on the macroeconomic adverse scenario used for the banking sector stress tests. An econometric model was estimated that relates macrofinancial variables used in the adverse scenario (short and longterm interest rates, VIX index, equity market, term spread) to net flows measured at the fund strategy level (EM, HY etc.). ${ }^{6}$ Additional variables were included such as HY bond spreads and EM bond spreads. Depending on the country analyzed, other macrofinancial variables might be relevant as well such as exchange rates, for example. The model can then be used to forecast net flows under the adverse scenario, using the value of the macrofinancial variables in this setting. ${ }^{7}$

In the Luxembourg FSAP, separate regressions were estimated for each type of funds (HY, EM, bond and mixed funds) using a set of macrofinancial variables (monthly change in 3Month Euribor, 10-year euro area sovereign yield, term spread, VIX, Eurostoxx 50) and additional financial variables (HY bond spreads for HY and mixed funds, EM bond spread for EM funds and other bond funds): ${ }^{8}$

$$
\text { Flows }_{t}=\alpha_{1} \Delta V I X_{t}+\alpha_{2} \Delta 3 M_{t}+\alpha_{3} \Delta 10 Y_{t}+\alpha_{4} \Delta \text { Term }_{t}+\alpha_{5} \Delta \text { Eurostox }_{t}+\alpha_{6} \Delta \text { Spread }_{t}+\varepsilon_{t}
$$

Net flows were then projected using the values of the macrofinancial variables in the adverse scenario, converted to monthly frequency (Table 4).

\footnotetext{
${ }^{5}$ The integration of the macroeconomic scenario into funds' liquidity stress tests is one-step further towards system-wide stress testing as severe shocks to banks and funds can be assessed at the same time. Ideally, the model would also feature feedback loops between financial markets, banks and funds, which are outside the scope of this paper. Preliminary work by the FSB attempts at filling this gap.

${ }^{6}$ Panel estimation was also explored, but there is wide heterogeneity at the fund level regarding net flow pattern, which resulted in non-significant results.

${ }^{7}$ Banking sector stress tests typically use quarterly data while investment fund stress tests use higher-frequency data (monthly). Therefore, the values of the macrofinancial variables must be converted to monthly frequency.

${ }^{8}$ The spread variables were not included in the adverse scenario used for the banking sector stress tests. Hence additional assumptions were required. For the Luxembourg FSAP, the highest monthly change in spreads observed over 2007-2016 was applied.
} 
Table 4. Macrofinancial variables in the adverse scenario

\begin{tabular}{cccc}
\hline & Initial value & Projection & Change \\
\hline 3M-Euribor & -0.33 & -0.13 & 0.20 \\
EA 10-Year & 1 & 1.32 & 0.33 \\
Term spread & 1.33 & 1.45 & 0.13 \\
Eurostoxx 50 & 100 & 94 & $6 \%$ \\
VIX & 14.8 & 23.44 & $58 \%$ \\
EM spreads (bps) & 478 & 858 & 380 \\
HY Spreads (bps) & 498 & 1076 & 578 \\
\hline
\end{tabular}

Sources: Thomson Reuters Datastream and IMF staff calculations.

Finally, net flows were obtained by combining the econometric model with the value of the projected macrofinancial variables (Table 5). The comparison between Table 3 and Table 5 shows that redemption shocks are typically higher when estimated at the individual fund level (historical approach) than when estimated at the fund strategy level.

\section{Table 5. Projected net outflows in the adverse scenario}

\begin{tabular}{cc}
\hline & $\begin{array}{c}\text { (in percent of total net assets) } \\
\text { Redemption shock (\% TNA) }\end{array}$ \\
\hline EM & $9 \%$ \\
HY & $11 \%$ \\
Mixed funds & $-11 \% *$ \\
Other bond funds & $6 \%$ \\
\hline Sources: $\mathrm{BCL}$; CSSF; and IMF Staff calculations. \\
*Under the adverse scenario, mixed funds would \\
experience net inflows.
\end{tabular}

Figure 6 shows the observed and estimated net flows for each fund strategy. 
Figure 6. Observed and Estimated Net Flows by Fund Strategy

HY Fund Flows

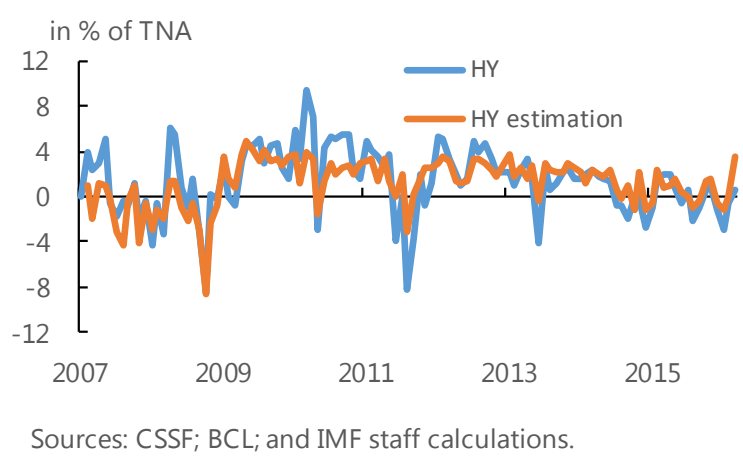

Bond fund flows

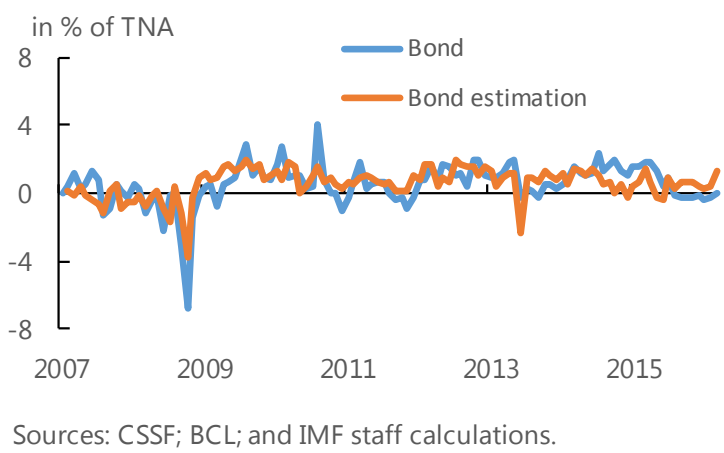

EM Fund flows

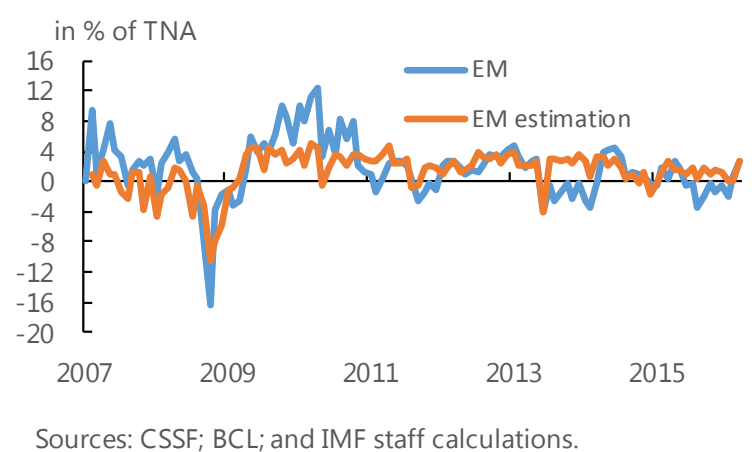

Mixed fund flows

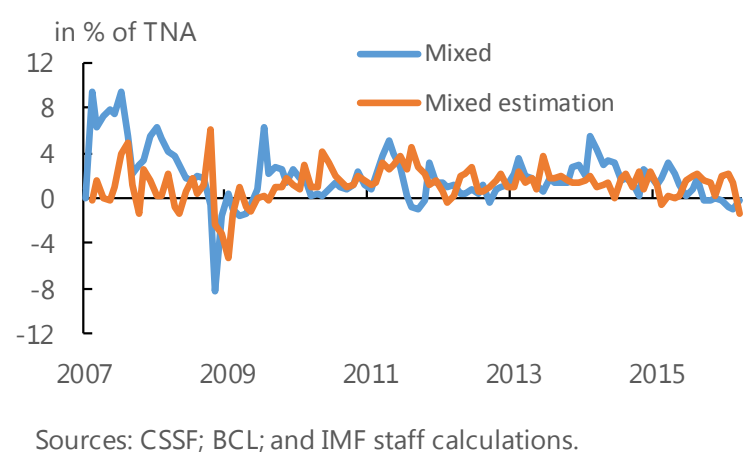

\section{Measurement of Liquidity Buffers}

Measuring liquidity on the asset side of funds is notoriously more difficult, especially for funds investing in fixed income instruments, due to data gaps regarding liquidity indicators. Most corporate and sovereign bonds are traded Over-The-Counter (OTC) rather than on electronic platforms, hence data on volumes and trades are often difficult to obtain. Other liquidity indicators such as bid-ask spreads might not be entirely reliable given that they are based on indicative prices, as most corporate bonds trade very infrequently.

Several methods can be used: i) time to liquidation approach (based on aggregated or security-by-security data), and ii) grouping securities by liquidity buckets (tiered approach).

The first method uses aggregated data which are not always available or reliable (dealer inventories or turnover for example) or rely on security-level data. In this case, sophisticated models are used to estimate the price impact of trades at the individual security level, which can be resource-intensive or expensive, when such a task is outsourced to third-party 
providers. Therefore, the emphasis is put on the tiered approach, where assets are grouped by liquidity buckets.

\section{Time to liquidation approach (TTL) using security-level data}

Under the TTL approach, the liquidity of each security in the portfolio is assessed by estimating the number of days that would be required to sell a given portion of the security, without causing a large price impact. This approach requires the use of a model that can estimate the TTL for each security, which can be outsourced to third-party providers. ${ }^{9}$ Such an approach was used for the Ireland FSAP, for a sample of 40 funds (20 EM and $20 \mathrm{HY}$ funds).

The TTL approach is not straightforward to use, as it requires trading data that might be unavailable, especially for fixed income instruments, or computations can be particularly cumbersome and/or expensive when outsourced, especially if the sample of funds is large. ${ }^{10}$

\section{Time to liquidation approach (TTL) using aggregated data}

The TTL approach can alternatively use aggregated data on liquidity by asset classes (corporate bonds, sovereign bonds etc.). For the U.S. FSAP, the redemption shock led to a measure of selling pressure computed as the sum of assets sold by individual funds hit by a redemption shock within the same fund style, which was then compared to dealer inventories to estimate the ability of funds' managers to sell their assets without causing fire sales. For the Sweden FSAP, the selling pressure was compared to turnover data. When data is available, the use of this approach is straightforward. However, the lack of granularity introduces some biases: for example, liquidity measures for corporates bonds do not distinguish between IG and HY bonds, which tend to overstate the liquidity of HY funds. ${ }^{11}$

\section{Tiered approach: High-Quality Liquid Assets (HQLA)}

The HQLA approach is closely related to the Liquidity Coverage Ratio (LCR) used for banks under Basel III liquidity regulatory requirements. ESMA (2015) recently used an HQLA approach to assess the liquidity of funds' assets. Securities in the portfolio are split by asset classes (sovereign bonds, corporate bonds, equities etc.) and ratings, and each grouping is

\footnotetext{
${ }^{9}$ For example, the Bloomberg LQA function provides estimates for each bond, based on market data from similar bonds; other providers such as MSCI LiquidMetrics offer similar services.

${ }^{10}$ For example, for the Luxembourg FSAP, a sample of 191 funds was used, which resulted in a portfolio of around 22,000 individual securities.

${ }^{11}$ Estimates from the empirical literature can also be used to assess the price impact of trades. For example, Greenwood et al. (2015) and ECB (2015) make the assumption that $€ 10$ billion of trading imbalances lead to a price change of 10 basis points. However, the authors apply the same estimates by asset classes, without any distinction.
} 
given a liquidity weight. The weights are inspired from the ones proposed by the Basel Committee for the calculation of HQLA under Basel III (Table 4).

A liquidity index can then be computed using the liquidity weights and the share of each security (or grouping) in the fund portfolio:

$$
\text { Liquidity }_{t}=\sum_{k=1}^{n} \omega_{k} \times s_{t, k}
$$

Where $\omega_{k}$ is the liquidity weight for security $k$, and $s_{t, k}$ is the share of this security in percent of $\mathrm{TNA}^{12}$.

Table 6. Liquidity weights

\begin{tabular}{cccccc}
\hline & Cash & $\begin{array}{c}\text { Sovereign } \\
\text { bonds }\end{array}$ & $\begin{array}{c}\text { Corporate } \\
\text { bonds }\end{array}$ & Securitization & Equities \\
\hline AAA to AA- & $100 \%$ & $85 \%$ & $85 \%$ & \\
A+ to A- & $100 \%$ & $85 \%$ & $50 \%$ & $50 \%$ & $50 \%$ \\
BB+ to BBB- & $50 \%$ & $50 \%$ & $0 \%$ & \\
Below BBB- & $0 \%$ & $0 \%$ & $0 \%$ & \\
\hline Sources: Credit Quality Step; and IMF Staff calculations
\end{tabular}

By construction, funds investing in riskier securities such as HY bonds will have relatively low liquidity buffers under the HQLA approach, as those securities will not be included in the measure. Under stress, liquidity in HY bond market can significantly decline, as observed during the GFC, but some bonds might nevertheless be sold. Therefore, for funds investing in less liquid asset classes, complementary approaches based on Time to Liquidation might also be considered.

\section{Tiered approach: cash and short-term debt securities}

An alternative approach focuses on cash and short-term debt securities (with a residual maturity of less than one year) to measure liquidity buffers (ESRB (2016)). For euro area countries, this approach is easy to use as each individual fund already reports balance sheet data to their national central bank on a quarterly basis.

The inclusion of cash in liquidity buffers under the tiered approach is debatable as i) fund managers typically try to be fully invested (i.e. to have very low cash buffers) to avoid deviations to the benchmark they target under the investment policies, and ii) most cash on

\footnotetext{
${ }^{12}$ If the analysis is done on a large sample of funds, collecting security-by-security data might be cumbersome and difficult. Therefore, it is also possible to group securities by buckets depending on the issuer type (sovereign, corporates) and ratings. Appendix 1 provides additional details on options to derive the HQLA measures from aggregated data and compares the results with security-level data.
} 
hand is used for operational purposes (such as purchases of bonds at issuance, delays in settlements of transactions, variation margins on derivatives etc.) - although part of the cash might also be held to cope with redemption requests. ${ }^{13}$

On one extreme, cash is considered fully operational and hence should not be included in the liquidity buffers. On the other extreme, cash is considered in full as a liquidity buffer, which in turn means that fund managers can withdraw all their deposits at banks to meet redemptions, which is further explored in the section on bank-fund interlinkages.

\section{A case study: top $50 \mathrm{HY}$ and EM bond funds in the U.S. and in Europe}

For the sample of 200 funds, the HQLA measure is computed using aggregated data, as detailed in Appendix 1. The portfolio of each fund is split into cash, sovereign bonds by rating, corporate bond by ratings, equities and other assets. Table 7 shows that liquidity buffers are higher for EM bond funds than for HY funds, due to a highest exposure to sovereigns for EM bond funds, which results in higher liquidity weights, while HY funds are by definition more exposed to high yield corporate bonds, with zero weight.

Table 7: HQLA measure

(in percent of TNA)

\begin{tabular}{ccc}
\hline & Average & Median \\
\hline \multicolumn{3}{c}{ United States } \\
\hline EM & $33 \%$ & $28 \%$ \\
HY & $16 \%$ & $9 \%$ \\
\hline \multicolumn{3}{|c}{ Europe } \\
\hline EM & $41 \%$ & $36 \%$ \\
HY & $23 \%$ & $9 \%$ \\
\hline
\end{tabular}

Sources: Bloomberg L.P., IMF Staff calculations

\section{A case study: Luxembourg}

Table 8 shows average liquidity buffers for the sample of bond funds used in the Luxembourg FSAP. Liquidity buffers measures by cash and short-term debt securities are relatively close between EM and bond fund, higher for mixed funds and lower for HY funds, indicating higher maturity transformation. The HQLA measure shows that other bond funds, mixed funds and EM funds have sizeable buffers while HY funds have more limited highly liquid assets, in line with their investment policy.

\footnotetext{
13 A recent paper by Morris et al. (2017) shows that fund managers tend to hoard cash in advance of anticipated investors' redemptions and funds investing in less liquid asset classes tend to hoard more than other funds. From that perspective, since managers hoard cash in advance of redemptions, they are likely to amplify fire sales.
} 
Table 8. Liquidity buffers (percent of total net assets)

\begin{tabular}{ccc}
\hline & $\begin{array}{c}\text { Cash and short- } \\
\text { term debt }\end{array}$ & HQLA \\
\hline EM & $16 \%$ & $42 \%$ \\
HY & $12 \%$ & $12 \%$ \\
Mixed funds & $31 \%$ & $55 \%$ \\
Other bond funds & $20 \%$ & $56 \%$ \\
\hline
\end{tabular}

\section{Liquidation approaches}

Once the redemption shock is calibrated, additional assumptions are needed to model the behavior of fund managers. The two main liquidation methods are the waterfall approach and the prorata approach.

Under the waterfall approach (Scholes (2000)), fund managers are assumed to liquidate their most liquid assets (IG sovereign bonds, cash) first before using less liquid securities. However, fund managers are constrained by the prospectus of the fund, which defines the usual composition of the portfolio of the fund. For example, a HY fund would need to keep a significant share of its portfolio invested in HY bonds to avoid any breach of the investment policy. There is mixed evidence regarding the waterfall approach. On the one hand, Manconi et al. (2012) provide evidence that, during the GFC, funds investing in securitized bonds started to sell first their (more liquid) corporate bonds rather than their illiquid ABS. On the other hand, Hau and Lai (2016) show that during the GFC, equity funds sold less liquid stocks first, keeping the most liquid stocks as buffers, the opposite of what would be expected under the waterfall approach.

Under the prorata approach, managers try to keep the structure of the portfolio constant by selling all securities in the portfolio in the same proportion (Cetorelli et al. (2016)). Such a strategy allows managers to ensure that the portfolio composition follows the investment policy.

In stress periods, managers might likely use a mix of both approaches to ensure that they are able to raise cash quickly to meet redemptions, while limiting the distortion of their portfolio. In recent FSAPs (U.S., Sweden and Luxembourg), both approaches were used. ${ }^{14}$

\footnotetext{
${ }^{14}$ For the Luxembourg FSAP, the prorata and waterfall approaches were applied only to the liquidity buffers of the fund and not to the overall portfolio.
} 
Table 9 summarizes the different approaches that were used in recent IMF FSAPs. Since different methods have been used, results for the liquidity stress tests are not directly comparable across countries.

\begin{tabular}{|c|c|c|c|c|c|c|c|c|}
\hline & \multicolumn{4}{|c|}{ Redemption shock } & \multicolumn{2}{|c|}{ Liquidity buffers } & \multirow{2}{*}{$\begin{array}{l}\text { Liquidation } \\
\text { method }\end{array}$} & \multirow{2}{*}{$\begin{array}{l}\text { Measure of } \\
\text { resilience }\end{array}$} \\
\hline $\begin{array}{l}\text { Country } \\
\& \text { reference }\end{array}$ & Threshold & Method & Scope & Freq. & Method & Scope & & \\
\hline $\begin{array}{l}\text { U.S. } \\
\text { (IMF } \\
(2015 \mathrm{c})\end{array}$ & $1 \%$ & $\begin{array}{c}\text { Historical } \\
\text { distribution }\end{array}$ & $\begin{array}{l}\text { Fund } \\
\text { style }\end{array}$ & $\mathrm{M}$ & TTL & Agg & $\begin{array}{c}\text { Prorata and } \\
\text { waterfall }\end{array}$ & $\begin{array}{c}\text { Selling } \\
\text { pressure/Dealer } \\
\text { inventories }\end{array}$ \\
\hline $\begin{array}{l}\text { Sweden } \\
\text { (IMF } \\
\text { (2016b) }\end{array}$ & $1 \%$ & $\begin{array}{c}\text { Historical } \\
\text { distribution }\end{array}$ & $\begin{array}{l}\text { Fund } \\
\text { style }\end{array}$ & Q & TTL & Agg & $\begin{array}{l}\text { Prorata and } \\
\text { waterfall }\end{array}$ & $\begin{array}{c}\text { Selling } \\
\text { pressure/Turnove } \\
\mathrm{r}\end{array}$ \\
\hline $\begin{array}{c}\text { Luxembourg } \\
\text { (IMF } \\
(2017 \mathrm{a})\end{array}$ & $\begin{array}{l}1 \% \text { and } \\
\text { model }\end{array}$ & $\begin{array}{l}\text { i) Historical } \\
\text { distribution, } \\
\text { ii) macro } \\
\text { approach }\end{array}$ & $\begin{array}{l}\text { Indiv. } \\
\text { funds } \\
\text { fund } \\
\text { style }\end{array}$ & $\mathrm{M}$ & $\begin{array}{l}\text { Tiered approach } \\
\text { (HQLA and short- } \\
\text { term assets) }\end{array}$ & $\begin{array}{l}\text { Agg } \\
\text { and } \\
\text { sec }\end{array}$ & $\begin{array}{c}\text { Prorata and } \\
\text { waterfall }\end{array}$ & $\begin{array}{l}\text { Redemption } \\
\text { coverage ratio }\end{array}$ \\
\hline $\begin{array}{l}\text { Ireland } \\
(\mathrm{IMF} \\
(2106 \mathrm{a})\end{array}$ & $5 / 10 / 20 \%$ & Ad hoc & $\begin{array}{l}\text { Indiv. } \\
\text { funds }\end{array}$ & $\mathrm{D}$ & TTL & $\mathrm{sec}$ & Prorata & $\begin{array}{c}\text { Time to } \\
\text { Liquidation }\end{array}$ \\
\hline
\end{tabular}

Note: Freq is frequency. Q is quarterly, $\mathrm{M}$ is monthly and $\mathrm{D}$ is daily. TTL stands for Time to Liquidation. Agg: Aggregated dat; sec: security-level data.

\section{E. How to Measure the Resilience of Investment Funds}

Once redemption shocks have been calibrated and liquidity buffers estimated, the resilience of investment funds to liquidity shocks can be measured by the Redemption Coverage Ratio (RCR):

$$
R C R=\frac{\text { Liquid assets }}{\text { Net outflows }}
$$

The RCR measures the ability of funds' liquidity buffers to meet investors' redemptions in the stress scenario.

If the RCR is above 1, then the fund has enough liquid assets to cope with the redemption shock. If the RCR is below 1, the fund will have to sell less liquid assets, possibly at a discount. If those sales cannot be absorbed easily by the market based on prevailing market liquidity conditions, investors into the fund will bear the losses. If the selling pressure is large 
enough, then it can deteriorate market liquidity for those instruments and lead to contagion effects across other investors.

The measure of liquid assets can be based on the HQLA approach, cash and short-term debt securities or TTL. For the latter, liquid assets would be equal to the share of securities in the portfolio that could be sold in less than a given number of days, typically aligned to the frequency of the flow data used to calibrate the redemption shock, and/or the redemption frequency of the fund.

For funds with an RCR below 1, the liquidity shortfall can be measured (in percent of TNA) as:

$$
\text { Liquidity shortfall }=\text { Net outflows }- \text { Liquid assets }
$$

\section{A case study: top $50 \mathrm{HY}$ and EM bond funds in the U.S. and in Europe}

Under the historical approach, most EM bond funds have enough liquid assets to meet the redemption shock. However, a large portion of HY funds have liquidity shortfalls as their liquidity buffers would not be enough to cover the redemption shock.

Table 10: Stress test results

\begin{tabular}{ccc}
\hline & $\begin{array}{c}\text { Average } \\
\text { redemption } \\
\text { shock (\% TNA) }\end{array}$ & HQLA \\
\hline U.S. EM Bond Funds & $14 \%$ & $12 \%$ \\
Europe EM Bond Funds & $15 \%$ & $6 \%$ \\
U.S. HY Bond Funds & $9 \%$ & $40 \%$ \\
Europe HY Bond Funds & $13 \%$ & $58 \%$ \\
\hline
\end{tabular}

Sources: Bloomberg L.P., IMF Staff calculations

Notes: Figures in gray panels depict the percentage of funds

in the sample unable to cover the redemption shock.

For funds with an RCR below 1, Figure 7 shows that for some funds, the liquidity shortfall is particularly large, i.e. higher than 10 percent of TNA, implying that if the redemption shock would materialize, fund managers might need to use liquidity management tools or sell assets at deep discounts. 


\section{Figure 7: Liquidity shortfall and RCR}

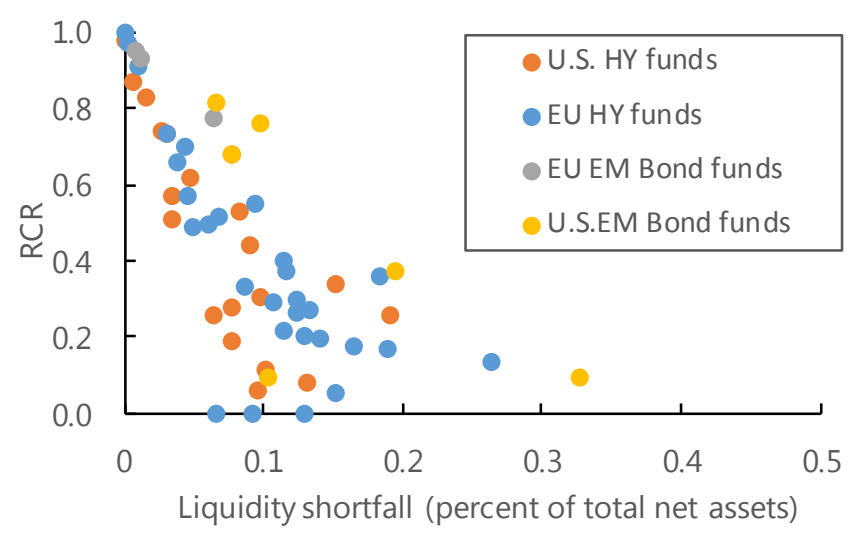

\section{A case study: Luxembourg}

For the Luxembourg FSAP, the results of the liquidity stress tests under the historical approach are summarized in Table 11. Results show that i) MMFs have enough liquid assets to cope with severe redemption shocks and ii) EM and HY funds would experience more difficulties (RCR below one) due to lower liquid assets measured by short-term assets or HQLA (for HY funds only).

Under the HQLA approach, the median RCR for HY funds is 50 percent implying that HQLA could only cover half of the redemption shock. For some HY funds (Figure 8), the liquidity shortfall would be above the borrowing limit under the UCITS Directive (10 percent of TNA), implying that funds would have to use LMTs, or sell assets at deep discount, impacting issuers and holders of those securities, and/or suspend redemptions.

\section{Figure 8. Liquidity Shortfall for Selected Funds}

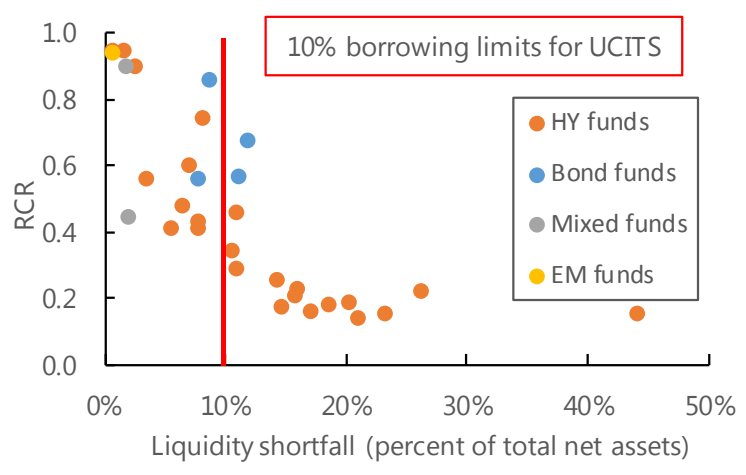


Table 11. Stress test results for the historical approach

(percent of funds whose liquid assets do not cover redemptions in severe shock scenario)

\begin{tabular}{cccc}
\hline & \multicolumn{3}{c}{ Historical approach } \\
& $\begin{array}{c}\text { Average redemption } \\
\text { shock (\% TNA) }\end{array}$ & ST debt & HQLA \\
& $19 \%$ & $0 \%$ & $\wedge$ \\
Short Term CNAV & $23 \%$ & $0 \%$ & $\wedge$ \\
Short Term VNAV & $18 \%$ & $0 \%$ & $\wedge$ \\
Other MMFs & $18 \%$ & $71 \%$ & $2 \%$ \\
EM & $19 \%$ & $78 \%$ & $75 \%$ \\
HY & $9 \%$ & $28 \%$ & $5 \%$ \\
Mixed funds & $18 \%$ & $52 \%$ & $8 \%$ \\
\hline Other bond funds & &
\end{tabular}

Sources: BCL; CSSF; and IMF Staff calculations. ${ }^{\wedge}$ The HQLA measure is not used for MMFs.

Under the macroeconomic approach, results are milder (Table 8), since redemption shocks are generally lower.

Table 12. Stress test results for the macroeconomic approach

(percent of funds whose liquid assets do not cover redemptions in severe shock scenario)

\section{Forward-looking approach}

\begin{tabular}{cccc} 
& $\begin{array}{c}\text { Average redemption } \\
\text { shock (\% TNA) }\end{array}$ & $\begin{array}{c}\text { ST debt } \\
\text { ST }\end{array}$ & HQLA \\
\hline Short Term CNAV & $*$ & & \\
Short Term VNAV & $*$ & $50 \%$ & $0 \%$ \\
Other MMFs & $*$ & $66 \%$ & $69 \%$ \\
EM & $9 \%$ & $* *$ & $* *$ \\
HY & $11 \%$ & $30 \%$ & $0 \%$ \\
Mixed funds & $* *$ & & \\
Other bond funds & $6 \%$ &
\end{tabular}

\section{A case study: Ireland}

In the Ireland FSAP, using the TTL approach at security-level and assuming prorata liquidation, most funds in the sample would be able to liquidate their holdings within a limited number of days (Figure 9). On a relative basis, EM bond funds would be able to sell their assets more quickly than HY funds (IMF (2016a)). 


\section{Figure 9. Liquidity stress test results for Irish EM and HY funds}

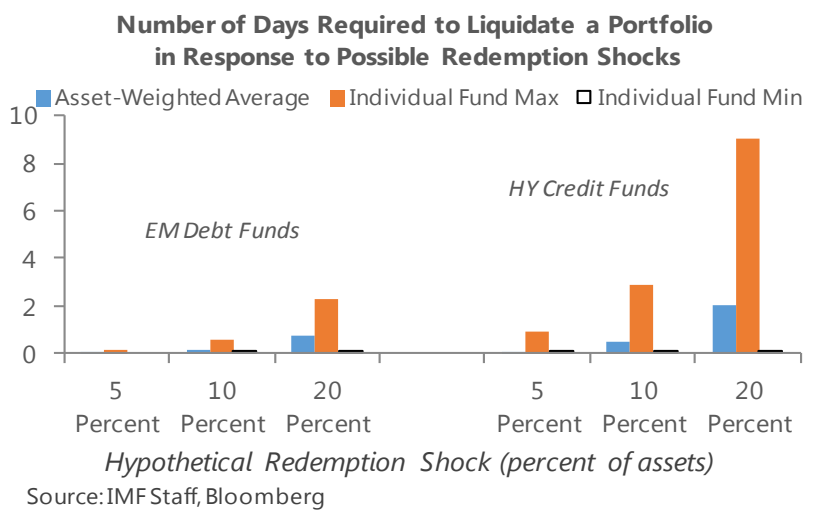

A case study: The U.S.

The liquidity stress test for U.S. mutual funds (IMF (2015c)) shows that municipal and corporate bond markets would likely experience strong selling pressure following the realization of a severe redemption shock (Figure 10). The selling pressure stemming from mutual funds would be three to four times larger than liquidity buffers (measured by dealers' inventories).

\section{Figure 10. Liquidity Stress Tests Results for the U.S.}

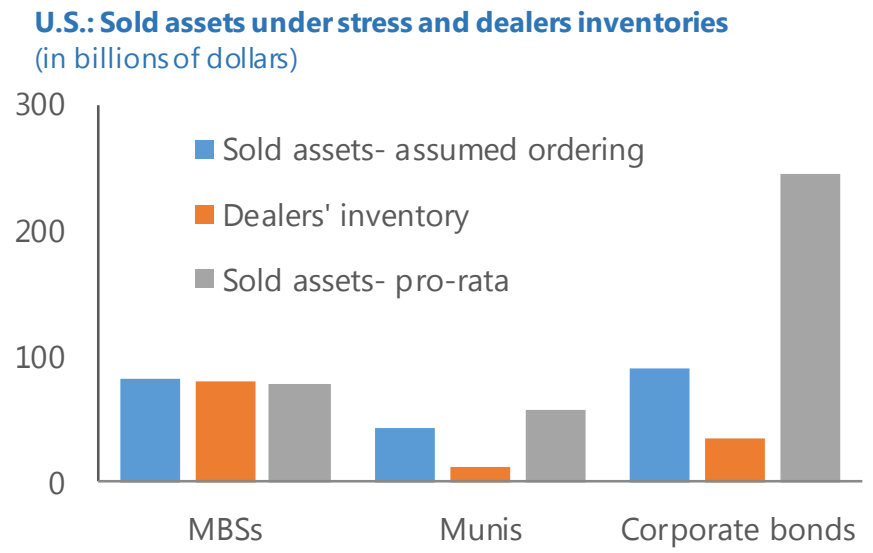

Note: "Sold assets pro-rata" represent assets sold by mutual funds hit by a tail event redemption shock that have to sell their assets pro-rata, i.e. by making sure that the structure of assets remains intact (approach 1). "Sold assets assumed ordering" represent assets sold by mutual funds hit by a tail event redemption shock that have to sell their assets in descending order (approach 2).

Sourrce: IMF Staff calculations. 


\section{A case study: Sweden}

Liquidity stress test results for Sweden indicate that funds investing in domestic corporate bonds would be more exposed to redemption risks (IMF (2016b)), as the market would not be able to absorb the selling pressures, without large decline in prices (Figure 11).

\section{Figure 11. Liquidity Stress Test Results for Sweden}

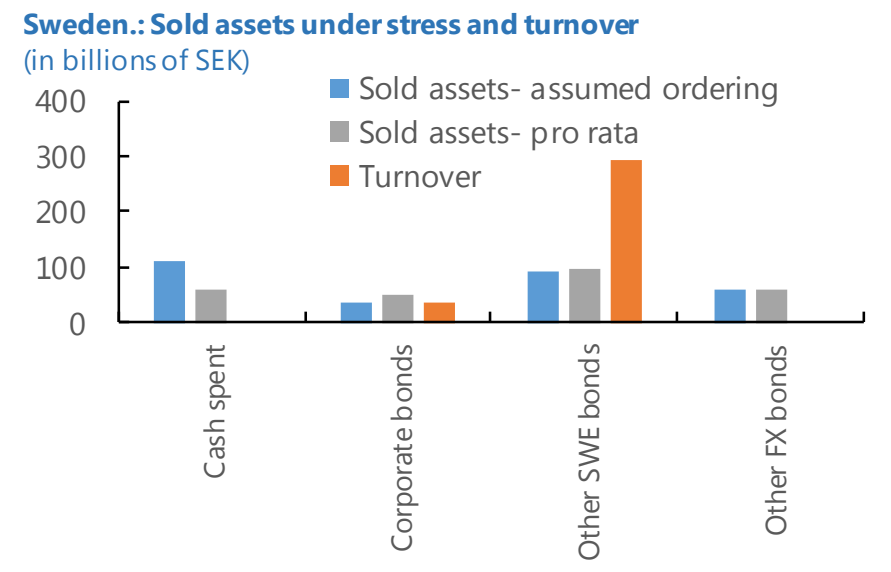

Note: "Sold assets pro-rata" represent assets sold by mutual funds hit by a tail event redemption shock that have to sell their assets pro-rata, i.e. by making sure that the structure of assets remains intact (approach 1). "Sold assets assumed ordering" represent assets sold by mutual funds hit by a tail event redemption shock that have to sell their assets in descending order (approach 2).

Sourrce: IMF Staff calculations.

\section{BANK-FUND INTERLINKAGES}

\section{A. Overview}

Stress in the fund industry can propagate to the banking sector through different channels. Direct channels include: i) holdings of investment funds shares by banks, ii) funds' deposits in banks, and iii) banks as counterparties to derivatives transactions or securities financing transactions (repurchase agreements and securities lending) by funds and iv) bank loans to funds. Indirect channels include: i) holding of bank debt by funds, ii) holding of bank equities by funds, and iii) common exposures by funds and banks.

\section{Direct Channels}

Typically, banks have very limited exposures to funds on the asset side: banks' holdings of funds shares are low, and loans to investment funds are usually limited, in part due to regulatory requirements which constrain the ability of investment funds to borrow from banks (except as a temporary measure). 
However, deposits from funds into banks can be sizeable, especially for depositary banks. Finally, derivatives exposures can be significant, but typically limited granularity on derivatives data prevent an economic analysis of those exposures. ${ }^{15}$

\section{Indirect Channels}

Funds can hold bank debt or bank equity, and fire sales by funds could then affect the market value of banks. Additionally, banks and funds can share common exposures, typically towards sovereign issuers.

However, the common exposure channel could be weak given that i) funds with high liquidity mismatch invest in less liquid securities which are usually not held by banks (corporate bonds), and, ii) if common exposures relate to sovereigns, fire sales are generally less likely since sovereign markets are usually deeper than corporate bond markets. For some EMs or frontier markets however, the common exposure channel might play a more significant role.

\section{A case study: The Euro Area}

Data from the euro area accounts (Table 9) show that on the asset side of funds, deposits account for the largest exposure to banks (€345 billion), followed by debt securities and bank equity ( $€ 56$ billion). Euro area bank debt securities account for less than 5 percent of debt securities held by funds (around 4 percent of euro area bank debt outstanding). Euro area bank equities account for 2 percent of equities held by funds, but the $€ 56$ billion held by funds amount to 14 percent of euro area bank equities.

\section{Table 13. Euro Area Investment Funds Exposures to Euro Area Banks}

\begin{tabular}{|lclc|}
\hline \multicolumn{2}{|c|}{ Assets (€ billion) } & \multicolumn{2}{c|}{ Liabilities (€ billion) } \\
\hline Cash & 345 & Loans & 64 \\
Debt securities & 183 & Fund shares & 267 \\
Equities & 56 & & 331 \\
Total & 584 & Total & \\
& & & \\
\hline $\begin{array}{l}\text { Source: ECB. } \\
\text { Notes: Data as of June 2016 }\end{array}$ & &
\end{tabular}

\footnotetext{
${ }^{15}$ In the euro area, funds report derivatives on a gross basis (rather than net basis) and depending on the valuation date, derivatives can appear on the asset or liability side of the funds. For non-UCITS, the Alternative Investment Fund Manager Directive (AIFMD) require Alternative Investment Funds (AIF) to report data to their supervisors, although because the reporting is in its early days, data quality remains an issue.
} 


\section{A case study: Luxembourg}

Table 14 shows the exposures of Luxembourg funds to domestic banks. On the asset side of funds, most exposures are through cash deposits into banks ( $€ 101$ billion), with residual exposures through securities and derivatives. The significant exposure to banks is linked to the role of Luxembourg as a financial center for asset management activities. On the liability side, there is limited exposures, mainly through loans and derivatives, as banks barely hold funds shares.

\section{Table 14. Luxembourg Investment Funds Exposures to Banks}

\begin{tabular}{|c|c|c|}
\hline (as of June, 2016) & Banks in Luxembourg & Banks abroad \\
\hline $\begin{array}{l}\text { Investment funds' assets } \\
\text { of which: }\end{array}$ & 104 & 691 \\
\hline Debt securities & 1 & 330 \\
\hline Stocks & 0 & 72 \\
\hline Derivatives & 1 & 134 \\
\hline Deposits \& loans & 101 & 155 \\
\hline $\begin{array}{l}\text { Investment funds' liabilities } \\
\text { of which: }\end{array}$ & 8 & 175 \\
\hline Derivatives & 2 & 126 \\
\hline \multicolumn{3}{|c|}{ Source: BCL statistical reporting S.521 and investment fund reporting } \\
\hline \multicolumn{3}{|c|}{$\begin{array}{l}\text { Note: scope on the asset side: loans, equity instruments, debt instruments, derivatives; on the } \\
\text { liability side: loans, short sales and derivatives }\end{array}$} \\
\hline \multicolumn{3}{|c|}{$\begin{array}{l}\text { Note: exposures to Luxembourg's banks is from S.251, and exposures to banks abroad is the } \\
\text { residual subtracting from the investment funds total global exposures to banks from investment } \\
\text { funds' reporting. }\end{array}$} \\
\hline
\end{tabular}

Furthermore, depositary banks tend to have a large share of their deposits stemming from investment funds (around 40 percent in 2015) as shown in Figure 12.

\section{Figure 12. Bank Liabilities Accounted for by investment funds and MMFs in Luxembourg}

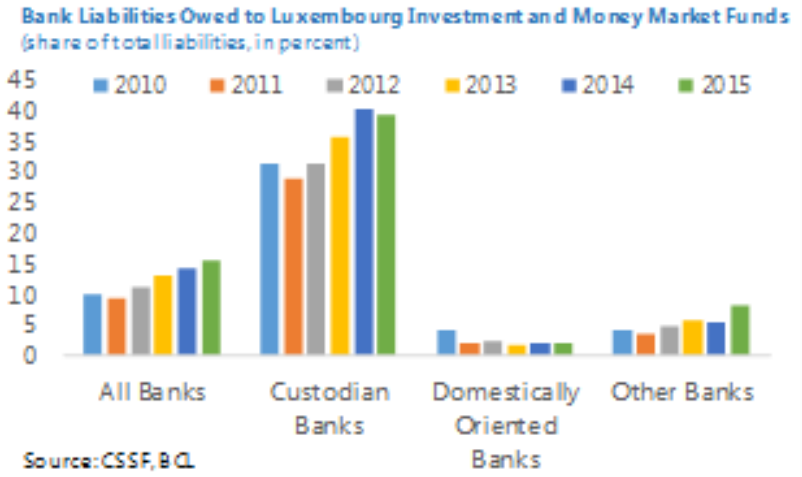

Overall, based on the Luxembourg FSAP experience, direct linkages between funds and banks through fund deposits into banks appear to be the main transmission channel. This is explored further in the next section. 


\section{B. Liquidity Stress Tests, Deposit Withdrawals and Depositary Banks}

Funds retain some fraction of their assets in cash (overnight deposit, term deposit etc.) for different reasons (delays in settlements, margin calls on derivatives, liquidity buffer etc.).

Funds typically diversify their deposits across banks to limit their exposure to the default of a bank.

In the context assumed in the liquidity stress test, funds subject to severe redemption shocks might need to withdraw their deposits to meet investors' redemptions, which in return could trigger liquidity pressures on banks, especially if funds' deposits account for a large share of bank deposits. Banks domiciled in financial centers for the fund industry, such as Ireland and Luxembourg, are more likely to be exposed to this type of risk.

Unfortunately, data on fund by fund exposure to individual bank is usually lacking. For example, in the euro area, while there is aggregated data on fund deposits into banks, granular data on individual fund exposures to banks is often lacking.

Therefore, to operationalize the analysis of interlinkages between banks and funds, assumptions need to be made regarding the identity of banks where funds park their cash.

For example, for EU countries, one can assume that all deposits are with the depositary bank. ${ }^{16}$ This assumption is quite strong as it does not take into account: i) the diversification across banks, and ii) the use of banks domiciled outside of the country.

Based on the results from the liquidity stress tests, deposit withdrawals estimates can be provided, especially when the method used allow the aggregation of the results (use of a macroeconomic scenario to calibrate the redemption shock). The impact of funds withdrawals on banks can then be compared with estimates provided by banks liquidity stress tests (LCR and other liquidity stress tests used in FSAPs).

\section{A case study: Luxembourg}

For the Luxembourg FSAP, under the adverse scenario, deposit outflows from banks were estimated to range between $€ 3$ and 7 billion (12 to 33 percent of funds' deposits in the sample) with significant variations across depositary banks. Banks that received deposits from funds more likely to experience stress (HY funds) and less diversified across a broad range of funds' strategies were more likely to experience significant deposit withdrawals.

\footnotetext{
${ }^{16}$ In the EU, under the UCITS Directive, funds are required to have a depositary bank domiciled in the country of the fund. The duties of the depositary bank are i) safekeeping of assets (custody duties and asset monitoring duties for other assets such as derivatives contracts), ii) oversight of the fund (NAV calculation, investment restrictions etc.), and iii) cash flow monitoring (i.e. ensuring that all cash is properly booked in segregated accounts in the name of the management company of the fund).
} 
Given that in the forward-looking approach mixed funds experience inflows, depositary banks face slightly lower deposits outflows when mixed funds are included (Table 15).

Deposit outflows are computed using two different liquidation methods. Under the waterfall approach, fund managers liquidate their most liquid securities first, and then use cash to cover the residual redemptions. Under the prorata approach, managers liquidate cash and securities in proportion of their share in their liquidity buffers. Hence, a portion of cash is always used to cover redemptions, resulting in larger deposits outflows. Under the prorata approach, if the proportional liquidation of HQLA and cash is insufficient, then the fund draws on the remaining cash to meet redemptions.

For example, if cash accounts for 5 percent of TNA and HQLA securities for 15 percent, then cash accounts for 25 percent of the liquidity buffers $(5 / 20)$. If this fund faces a redemption shock of 10 percent of TNA, under the prorata approach, cash will be used to cover $1 / 4$ of the shock (2.5 percent of TNA) and HQLA securities to cover the rest (7.5 percent of TNA). For the same fund, under the waterfall approach, deposit outflows are zero as HQLA are enough to cover the redemption shock (15 percent vs 10 percent).

Table 15. Deposit Outflows Under the Forward-Looking Approach

\begin{tabular}{|c|c|c|}
\hline & $\begin{array}{l}\text { Including mixed } \\
\text { funds }\end{array}$ & $\begin{array}{l}\text { Without mixed } \\
\text { funds }\end{array}$ \\
\hline Total deposits & 24.7 & 21.6 \\
\hline Deposit outflows (waterfall) & 3.0 & 3.3 \\
\hline $\begin{array}{c}\text { Deposit outflows } \\
\text { (waterfall, in \% of fund } \\
\text { deposits) }\end{array}$ & $12 \%$ & $15 \%$ \\
\hline Deposit outflows (prorata) & 6.8 & 7.2 \\
\hline $\begin{array}{c}\text { Deposit outflows (prorata, } \\
\text { in \% of fund deposits) }\end{array}$ & $28 \%$ & $33 \%$ \\
\hline $\begin{array}{l}\text { Deposit outflows (average } \\
\text { of waterfall and prorata) }\end{array}$ & 4.9 & 5.3 \\
\hline $\begin{array}{c}\text { Deposit outflows (average } \\
\text { of waterfall and prorata } \\
\text { in \% of funds deposits) }\end{array}$ & $20 \%$ & $24 \%$ \\
\hline
\end{tabular}

Sources: BCL CSSF, and IMF staff calculations. 


\section{CONCLUSION}

This paper provides a framework to design and perform liquidity stress test for investment funds. The approach is flexible enough to cope with different methodological assumptions and different degrees of data availability. The framework focuses on the resilience of individual funds or group of funds. Further efforts are needed to integrate the current framework in financial stability analyses. In particular, potential fire sales emanating from funds following investors redemptions need to be integrated to estimate possible spillovers on markets and other agents exposed to the same instruments.

Possible future work could focus on the design of stress tests for funds, along the lines of: i) modelling joint liquidity and market shocks, ii) taking into account the absorbing capacity of markets, and iii) including fire sales. Additional work on data gaps is also warranted, in particular regarding bank-fund interlinkages.

Finally, more exploratory work on integrating further bank-fund interlinkages would be required in order to perform system-wide stress tests, as recently recommended by the FSB (FSB (2017)). 


\section{REFERENCES}

Association of the Luxembourg Fund Industry, 2013, "Guidelines for UCITS Liquidity Risk Management", March.

Autorité des Marchés Financiers, 2016, "Public Consultation: Guide to the use of stress tests as part of risk management within asset management companies", August.

Cetorelli, N., F. Duarte and T. Eisenbach, 2016, “Are Asset Managers Vulnerable to Fire Sales?", Liberty Street Economics, Federal Reserve Bank of New York, February 18.

Coval, J. and E. Stafford, 2007, “Asset fire sales (and purchases) in equity markets”, Journal of Financial Economics, Vol. 86, 479-512.

European Central Bank, 2015, "Systemic risk, contagion and financial networks", Financial Stability Review, November 2015.

European Securities and Markets Authority, 2015, "Measuring the Shadow banking system a focused approach", Trends, Risks and Vulnerabilities, No.2, 2015.

European Systemic Risk Board, 2016, "Risk Dashboard”, Issue 15, March 2016, Frankfurt.

Financial Stability Board, 2016, "Proposed Policy Recommendations to Address Structural Vulnerabilities from Asset Management Activities", Consultative Document, 22 June 2016, Basel.

—_ 2017, "Policy Recommendations to Address Structural Vulnerabilities from Asset Management Activities”, 12 January 2017, Basel.

Greenwood, R., A. Landier, and D. Thesmar, 2015, "Vulnerable Banks", Journal of Financial Economics, Vol. 115 (3), 417-485.

Hau, H. and S. Lai, 2016, “The Role of Equity Funds in the Financial Crisis Propagation”, Review of Finance, forthcoming.

International Monetary Fund, 2014a, "Making the Transition from Liquidity to GrowthDriven Markets”, Global Financial Stability Report, Chapter 1, April 2014, Washington D.C.

— 2014b, "Improving the Balance Between Financial and Economic Risk Taking", Global Financial Stability Report, Chapter 1, October 2014, Washington D.C.

_ , 2015a, "Enhancing Policy Traction and Reducing Risks", Global Financial Stability Report, Chapter 1, April 2015, Washington D.C. 
_ 2015b, "The Asset Management Industry and Financial Stability", Global Financial Stability Report, Chapter 3, April 2015, Washington D.C.

_ 2015c, "Stress Testing - Technical Note”, United States Financial Sector Assessment Program, IMF Country Report No. 15/173, July 2015, Washington D.C.

__ 2016a, "Technical Note —Asset Management and Financial Stability", Ireland Financial Sector Assessment Program, IMF Country Report No. 16/312, September 2016, Washington D.C.

— 2016b, "Sweden: Financial System Stability Assessment", Sweden Financial Sector Assessment Program, IMF Country Report No. 16/355, November 2016, Washington D.C.

—_, 2017a, "Luxembourg: Financial System Stability Assessment”, Luxembourg Financial Sector Assessment Program, IMF Country Report No. 17/122, May 2017, Washington D.C.

—_ 2017b, "Technical Note —Risk Analysis", Luxembourg Financial Sector Assessment Program, IMF Country Report No. 17/261, August 2017, Washington D.C.

Malik, S. and P. Lindner, 2017, “On Swing Pricing and Systemic Risk Mitigation”, IMF Working Paper, forthcoming, Washington D.C.

Manconi, A., M. Massa and A. Asuda, 2012, "The role of institutional investors in propagating the crisis of 2007-2008", Journal of Financial Economics, Vol. 104(3), 491-518, June.

Morris, S., I. Shim and H. Shin, 2017, "Redemption risk and cash hoarding by asset managers”, BIS Working Paper No. 608, January 2017.

Office of Financial Research, 2013, “Asset Management and Financial Stability”, September, Washington D.C.

Scholes, M., 2000, “Crisis and Risk Management”, American Economic Review, Vol. 90(2), $17-21$. 


\section{Appendix I. Estimating HQLA Measures Using Aggregated Data}

\section{Procedure}

This appendix provides details on how to compute the HQLA measure using aggregated data.

First, securities are grouped by buckets depending on the asset type (equity, debt, cash). Then, debt securities are grouped by issuer type (sovereign, corporates) and ratings. Table A.1 shows the composition of the portfolio for a fund.

\begin{tabular}{|l|l|}
\hline \multicolumn{2}{|c|}{ Table A.1: Example of Portfolio Composition by Issuer Type } \\
\hline Portfolio by issuers & Share (in percent of TNA) \\
\hline Sovereign & $40 \%$ \\
\hline Corporates & $55 \%$ \\
\hline Cash & $5 \%$ \\
\hline Total & $100 \%$ \\
\hline
\end{tabular}

Aggregated information on asset type, issuer type and ratings are typically available from commercial data providers but the split is typically done by issuer types and ratings but not both at the same time. Table A. 2 provides details on the ratings of debt securities but does not distinguish between corporates and sovereigns.

\begin{tabular}{|c|c|c|}
\hline \multicolumn{3}{|c|}{ TableA.2: Example of Portfolio Composition by Rating } \\
\hline Portfolio by rating & Share (in percent of securities) & Share in percent of TNA \\
\hline Investment grade & $60 \%$ & $60 \% \times 95 \%=57 \%$ \\
\hline High Yield & $40 \%$ & $40 \% * 95 \%=38 \%$ \\
\hline Total & $100 \%$ & $95 \%$ \\
\hline
\end{tabular}

Therefore, as a proxy, it is assumed that most investment grade issuers are sovereigns and the non-sovereign part is then attributed to corporates. This proxy tends to overestimate the 
liquidity of the fund since liquidity weights on IG sovereign bonds are higher than on corporates. Given that the table used for liquidity weights requires more granular data than available, averages are used, as shown in Table A.3.

\section{Table A.3: Liquidity Weights}

\begin{tabular}{|c|c|c|c|c|}
\hline $\begin{array}{l}\text { Portfolio by } \\
\text { issuer }\end{array}$ & $\begin{array}{l}\text { Initial } \\
\text { weights }\end{array}$ & $\begin{array}{l}\text { Weights used for } \\
\text { aggregate data }\end{array}$ & $\begin{array}{l}\text { Initial } \\
\text { weights }\end{array}$ & $\begin{array}{l}\text { Weights used for } \\
\text { aggregate data }\end{array}$ \\
\hline & Sovereign & Sovereign & Corporate & Corporate \\
\hline AAA to AA- & $100 \%$ & \multirow{3}{*}{$78 \%$} & $85 \%$ & \multirow{3}{*}{$62 \%$} \\
\hline $\mathrm{A}+$ to $\mathrm{A}-$ & $85 \%$ & & $50 \%$ & \\
\hline $\begin{array}{l}\mathrm{BBB}+\text { to } \\
\mathrm{BBB}-\end{array}$ & $50 \%$ & & $50 \%$ & \\
\hline Below BBB- & $0 \%$ & $0 \%$ & & $0 \%$ \\
\hline Cash & \multicolumn{4}{|c|}{$100 \%$} \\
\hline
\end{tabular}

Table A.4 shows the resulting HQLA indicator.

\begin{tabular}{|c|c|c|c|}
\hline \multicolumn{4}{|c|}{ Table A.4: Computation of HQLA indicator } \\
\hline $\begin{array}{l}\text { Portfolio by } \\
\text { issuer }\end{array}$ & $\begin{array}{l}\text { Share (in percent of TNA) } \\
{[\mathrm{A}]}\end{array}$ & $\begin{array}{l}\text { Liquidity weight } \\
{[\mathrm{B}]}\end{array}$ & $\begin{array}{l}\text { Liquidity index } \\
{[\mathrm{A}] \mathrm{x}[\mathrm{B}]}\end{array}$ \\
\hline Sovereign IG & $40 \%$ & $78 \%$ & $31 \%$ \\
\hline Sovereign HY & $0 \%$ & $0 \%$ & $0 \%$ \\
\hline Corporate IG & $17 \%$ & $62 \%$ & $10.5 \%$ \\
\hline Corporate HY & $38 \%$ & $0 \%$ & $0 \%$ \\
\hline Cash & $5 \%$ & $100 \%$ & $5 \%$ \\
\hline Total & $100 \%$ & & $46.5 \%$ \\
\hline
\end{tabular}


Altermatively, if it is assumed that most investment grade issuers are corporates, and the residual is attributed to sovereigns, the HQLA measure declines because IG corporate bonds receive a 62 percent liquidity weight as opposed to 78 percent for sovereigns (Table A.5).

\begin{tabular}{|c|c|c|c|}
\hline \multicolumn{4}{|c|}{ Table A.5: Alternative Computation of HQLA Indicator } \\
\hline $\begin{array}{l}\text { Portfolio by } \\
\text { issuer }\end{array}$ & $\begin{array}{l}\text { Share (in percent of TNA) } \\
{[\mathrm{A}]}\end{array}$ & $\begin{array}{l}\text { Liquidity weight } \\
{[\mathrm{B}]}\end{array}$ & $\begin{array}{l}\text { Liquidity index } \\
{[\mathrm{A}] \mathrm{x}[\mathrm{B}]}\end{array}$ \\
\hline Sovereign IG & $2 \%$ & $78 \%$ & $1.5 \%$ \\
\hline Sovereign HY & $38 \%$ & $0 \%$ & $0 \%$ \\
\hline Corporate IG & $55 \%$ & $62 \%$ & $34.1 \%$ \\
\hline Corporate HY & $0 \%$ & $0 \%$ & $0 \%$ \\
\hline Cash & $5 \%$ & $100 \%$ & $5 \%$ \\
\hline Total & $100 \%$ & & $40.6 \%$ \\
\hline
\end{tabular}

\section{Aggregate vs. Security-Level HQLA}

To assess the quality of the aggregated measure, we use a sample of 132 funds domiciled in Luxembourg, that were included in the liquidity stress test for the FSAP.

Chart A.1 shows that the aggregate measure performs relatively well, as most observations are close to the black line (which assumes that both measures are equal). The average difference between the two measures is 1.1 percentage point.

A simple regression of HQLA (using aggregated data) on security-level HQLA (red line in Chart A.1) gives a $\mathrm{R}^{2}$ of 64 percent. Moreover, both measures are very close for HY funds, which are more likely to be exposed to significant liquidity mismatches (Chart A.2). 


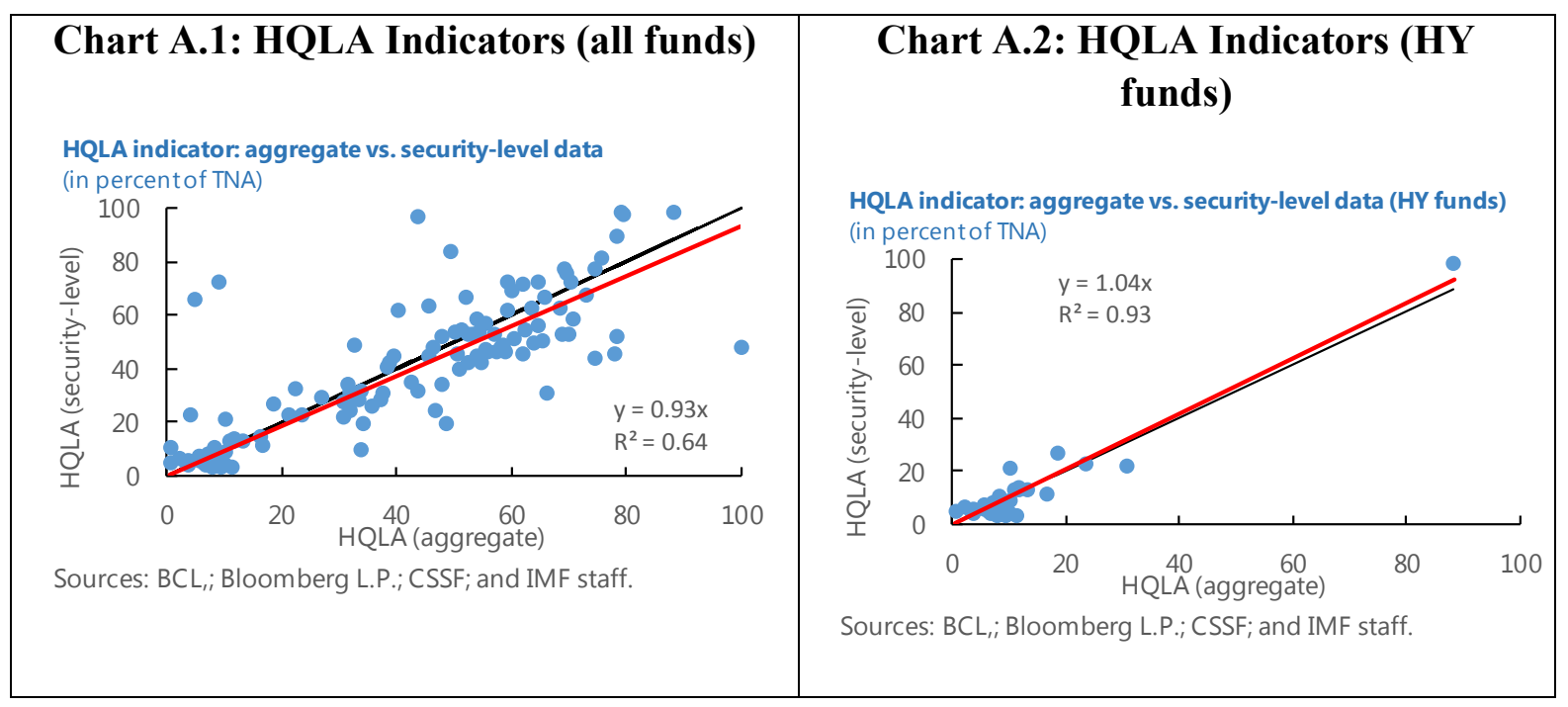

